\title{
25 Years On: a Look at Endangered Species
}

\author{
Richard Fitter
}

What has happened to the animals and birds listed as endangered species 25 years ago at IUCN's first technical meeting? The FPS Hon. Secretary investigates their present status and looks at the conservation methods that have proved most effective.

In August 1949 two lists of endangered species were drawn up, one of fourteen mammals, the other of thirteen birds, all described as 'in need of emergency action if they are to be saved from extinction'. This was at the First Technical Conference, at Lake Success, of the International Union for the Protection of Nature, as IUCN (the International Union for Conservation of Nature and Natural Resources) was then called. It is of some interest now, 25 years later, to review these lists and see what, if anything has been done to save these animals.

The mammals comprised two marsupials-thylacine and western banded anteater-chinchilla, Asiatic lion, Caribbean and Mediterranean monk seals, Addo bush elephant, mountain zebra, great Indian and Javan rhinos, Burmese brow-antlered deer, and three bovids-European bison, North African hartebeest and giant sable antelope.

Of these fourteen, two are now regarded as extinct: the Caribbean monk seal Monachus tropicalis, last definitely reported in 1952, which a very recent and thorough survey has failed to rediscover; and the North African or bubal hartebeest Alcelaphus buselaphus buselaphus, which has not been reliably reported since 1925 . Of the thylacine Thylacinus cynocephalus of Tasmania there has also been no recent scientifically verified sighting, though there have been a number of apparently well-founded but still unverified ones. This marsupial probably still does exist, but it is difficult to undertake conservation measures for an animal whose continued existence is not certain. It is fully protected by law. A fourth member of the original list, the Addo bush elephant, has been removed because it is no longer regarded as a separate taxonomic unit, but merely as an isolated population of the African elephant Loxodonta africana. In any case it is fully protected in a national park set up for the purpose. The western banded anteater, or rusty numbat, Myrmecobius fasciatus fasciatus appears to have recovered its numbers and was not deemed eligible for inclusion in either edition of the Red Data Book. It enjoys the same protection as the majority of Australia's native marsupial fauna.

The remaining ten mammals of the 1949 list are still threatened, in most cases despite the active and continuous attention of conservationists in the intervening years.

The chinchilla Chinchilla laniger is a severely depleted species of the Andes about which nobody has done very much in the past 
twenty years, apart from the Chilean authorities who are protecting their remaining wild stocks. It appears to survive nowhere else in the Andes except in Bolivia. However, so many are now bred in captivity for their fur that the species is unlikely to become extinct.

The Asiatic lion Panthera leo persica has also suffered a severe decline in numbers at its sole remaining habitat, the Gir Forest in Gujarat state, western India. Overgrazing by domestic cattle and buffaloes has reduced its natural ungulate prey to the point where the lion is dependent on domestic stock for its livelihood. This does not make it popular among the local inhabitants. However, determined efforts are being made to check the decline in numbers by setting aside a central area in the Forest, where domestic stock will be excluded and deer encouraged to rebuild their numbers to the point where they can again support a population of lions. A start has also been made in the establishment of a captive breeding stock, at the Junagadh Zoo in India, Kuala Lumpur Zoo in Malaya, and Jersey Zoo in the Channel Isles.

The Mediterranean monk seal Monachus monachus is probably the second most seriously endangered survivor, after the browantlered deer, from the 1949 list. Fishermen never love seals, and it is always hard to set up satisfactory seal reserves, especially in less developed countries. The Mediterranean monk seal rightly has a red sheet in the RDB, since no more than 500-1000 survive in the Mediterranean and on the Atlantic coast of North Africa. Its plight is not due to a lack of interest, but to the extreme difficulty of enforcing the law, although it is not yet legally protected in all the countries where it survives.

The mountain zebra Equus zebra zebra is one of a small group of ungulates (the bontebok Damaliscus dorcas and the white-tailed gnu Connochaetes gnou are others) which the citizens of South Africa almost exterminated but have now managed to save in various national parks and reserves-unlike the quagga Equus quagga which was exterminated. About 170 of these zebras now exist, most of them in the Mountain Zebra National Park in the Cape Province.

EUROPEAN BISON in the wild state in the forests of Bialowieza in 1959 Helmut Heimpel

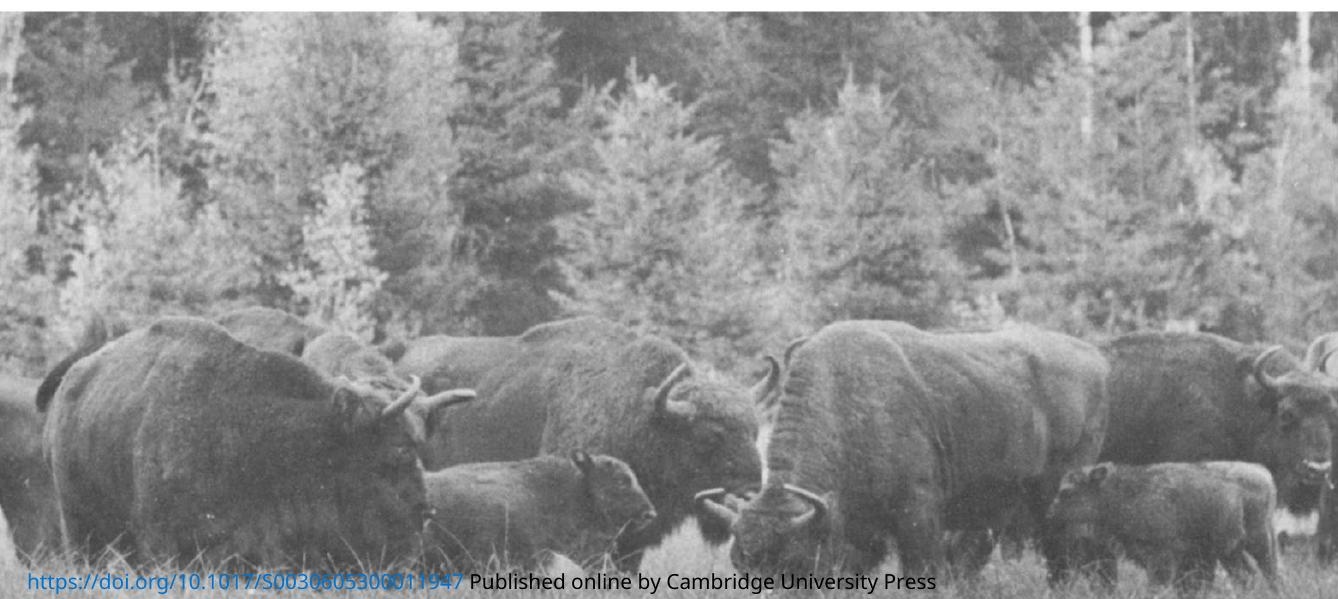




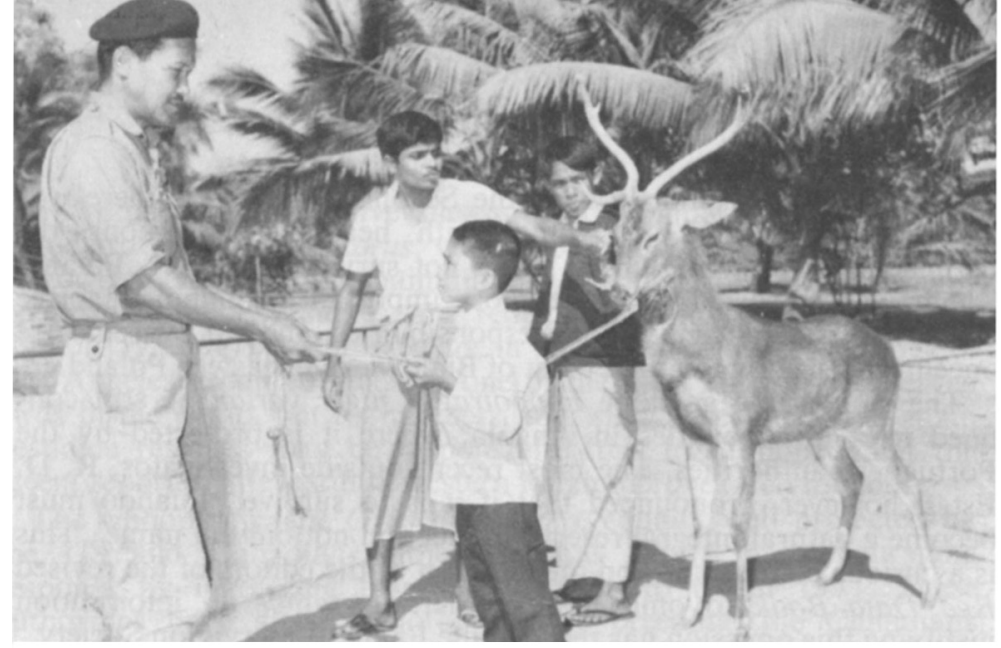

SAVED FROM SLAUGHTER. This Burmese brow-antlered deer Cervus eldi thamin, closely related to the endangered Manipur brow-antlered deer C.e. eldi. was found in March 1972 in the slaughterhouse at Rangoon by the young boy in the centre. He bought it from the man who had brought it in from the Myingyan district of Upper Burma and is seen presenting it to the Rangoon Zoo. This Burmese subspecies is not endangered and is fully protected. I he photograph appeared in the Rangoon paper The Mirror, and was sent to us by our correspondent $U$ Tun Yin.

The other race hartmannae is much more numerous, but still worthy of inclusion in the RDB.

The Javan rhino Rhinoceros sondaicus is one of the success stories. Thanks to vigorous intervention by the SSC, and the help of the Geigy Foundation, the Javan rhino's last known habitat, the Udjung Kulon reserve in western Java, has been provided with a continuing scientific presence, and numbers have increased from a bare two dozen to 44 at the last count. Javan rhinos may still also survive in other places, both in Indonesia and on the mainland. Efforts to preserve the great Indian rhino Rhinoceros unicornis in India and Nepal have been less successful, largely owing to poachers in search of rhino horn for the Chinese market. While most remaining populations are in national parks or reserves, poaching continues at a rate which will exterminate the great Indian rhino in the wild long before the end of the century unless this hazard can be controlled. Fortunately it breeds in several zoos, notably Basel.

The Manipur brow-antlered deer Cervus eldi eldi* is perhaps currently the most seriously endangered of the dozen survivors from the 1949 list. Only 50 individuals remain in its sole known locality, the Keibul Lanjao swamp south of the Logtak Lake in Manipur. What most needs to be done is to make its existing sanctuary secure from human harassment, but the difficult political situation in north-eastern India, has prevented this.

The European bison or wisent Bison bonasus is one of the few instances of an animal that has become extinct in the wild-and had indeed already become so by 1949 -but has been bred up in captivity in sufficient numbers to enable some to be reintroduced

* In the 1949 list this race was included with the Burmese race or thamin C.e. thamin, then also believed endangered. However, Talbot (Oryx, May 1960, page 262 ) showed that numbers were sufficient to justify removal from the endangered list. 
into the wild. Immediately after the Second World War there was natural anxiety that an animal with headquarters among the battlefields of eastern Europe might not survive. However, Poland, which was entrusted with the most important remaining captive stock, rose magnificently to its responsibilities, and wild wisents are once more browsing in the Forest of Bialowieza in eastern Poland.

The giant sable antelope Hippotragus niger variani is still confined to a few localities in Angola, where it is protected by the Portuguese authorities. The most recent outside investigator, R. D. Estes, however, pronounced that if it is to survive, 'Luando must become a natural integral reserve in fact and not only in name'. This is a curious commentary on the decision of the editors of the revised Red Data Book to omit it altogether. Certainly no information justifying this omission has reached the Fauna Preservation Society.

\section{Thirteen Birds}

Turning now to the birds, the following thirteen species were considered in 1949 to be in gravest danger of extinction: Arabian ostrich, cahow, ne-ne, Marianas mallard, Laysan duck, pink-headed duck, California condor, Marianas megapode, whooping crane, kagu, Eskimo curlew, eastern ground parrot and Cuban ivory-billed woodpecker.

Of these the Marianas mallard Anas oustaleti is not now regarded as a species, but as a hybrid between the mallard $A$. platyrhynchos and the grey mallard $A$. superciliosus. The pink-headed duck Rhodonessa caryophyllacea of India was, until a very recent plausible sighting in Nepal, regarded as almost certainly extinct, not having been reliably seen since 1935 . The Arabian ostrich Struthio camelus syriacus was also regarded as extinct, until a dying specimen was found on floodwater in Jordan in 1966. The Eskimo curlew Numenius borealis was likewise until recently believed extinct, but very small numbers have been seen on migration on the east coast of North America at intervals over the past 30 years, and an actual specimen was obtained in Barbados in 1963. Until the breeding grounds of these three species are rediscovered, it is not possible to do much to help them, though some people would maintain that it is better for them if their breeding grounds remain unknown. The eastern race of the Australian ground parrot Pezoporus wallicus wallicus is, however, said to be now fairly numerous. Of the Cuban ivory-billed woodpecker Campephilus principalis bairdii and the Marianas megapode Megapodius laperouse laperouse little or nothing seems to be currently known, the woodpecker because for political reasons Cuba has been more or less out of touch with the West for some years. Of the kagu Rhynochetos jubatus also, confined to the forests of New Caledonia, extraordinarily little seems to be known. The bird Red Data Book says it is very rare but can give no estimate of its numbers.

The remaining five species have all been the subject of active conservation programmes with varying degrees of success. The cahow or Bermuda petrel Pterodroma cahow was believed almost extinct when a small stock of under 50 pairs was rediscovered in 
1951. Since then intensive measures to combat the white-tailed tropicbird Phaethon lepturus, which competes for the same nesting burrows, have failed to maintain the stock at this level, perhaps because pesticide residues are reducing fertility. The California condor Gymnogyps californianus, in its limited range on the edge of Los Angeles urban complex, is one of the most carefully preserved birds in the world, but its numbers, too, slowly decline. Here again pesticide residues may be responsible. It is to be hoped that the recent report of a few still in western Mexico proves well founded.

The whooping crane Grus americana, equally well protected by the US and Canadian authorities, has shown an encouraging response by increasing from 33 in 1959 to 64 in 1971. These authorities have also promoted captive breeding, the Canadians collecting second eggs from clutches for the US Fish and Wildlife Service to hatch and rear. The Laysan duck Anas laysanensis has also been well protected by the US authorities, and is now as numerous in the wild as the small island of Laysan in the Hawaiian group permits, fluctuating between 400 and 600 . In addition there are a substantial number in captivity, breeding well. Captive breeding has been the sovereign remedy in the case of the ne-ne or Hawaiian goose Branta sandvicensis, which was at a very low ebb in the wild when the Wildfowl Trust began its triumphantly successful breeding programme. There are now many more in captivity than in the wild, although good numbers have been released on the islands of Hawaii and Maui, and appear to be re-establishing themselves.

\section{A Summary}

To summarise the fate of the 27 species or subspecies listed in 1949: two (Addo bush elephant and Marianas mallard) are no longer regarded as either species or subspecies, although their populations remain of great interest and are worthy of protection. Two (North African hartebeest and Caribbean monk seal) must now be regarded as extinct. Four more are so rare or so near extinction that little or nothing can be done to help them: thylacine, Arabian ostrich, pink-headed duck and Eskimo curlew. Of two more (Marianas megapode and Cuban ivory-billed woodpecker) so little is known' that again nothing effective can be done until we have ascertained their present status.

Of the 18 species about which something can and is being done, five-western banded anteater, chinchilla, Mediterranean monk seal, kagu and eastern ground parrot-are formally protected, but not the subject of any active management. None of them appear to be increasing, except perhaps the chinchilla in Chile, though both the banded anteater and the parrot appear to be in reasonable numbers again. Ten are the subject of active conservation or management programmes, successful in the case of the mountain zebra, Javan rhino, European bison, ne-ne goose, Laysan duck and whooping crane; less so or unsuccessful with the Asiatic lion, great Indian rhino, cahow and California condor.

Various methods have been employed in these management programmes, but status surveys over extensive areas, the usual first 
step, appear only to have been used for the great Indian rhino and the whooping crane. With most of these species, of course, stocks have already fallen so low, that the sole remaining site(s) are already well known, and only need periodical checking. It has not been possible to ascertain exactly which protective laws were brought in before or after 1949 , but apparently all those covered solely by protective laws (thylacine, western-banded anteater, chinchilla, Mediterranean monk seal, kagu and eastern ground parrot) were so protected already in 1949 .

The most important single method used to protect endangered species at present is the setting up of a national park or nature reserve, and once this has been done law enforcement becomes all important. Subject to the proviso in the last paragraph, this appears to have been already done in 1949 for the Cape mountain zebra, great Indian and Javan rhinos, and Laysan duck. Since 1949, however, new parks or reserves have been created for eight forms (Asiatic lion, Addo bush elephant, Manipur brow-antlered deer, giant sable antelope, California condor, whooping crane and Cuban ivory-billed woodpecker). For several of these species, notably the Asiatic lion, the Javan rhino and the California condor, it has also been possible to arrange for either a temporary or a continuing scientific presence. For several others, notably the great Indian rhino, the Manipur brow-antlered deer and the giant sable antelope, law enforcement is still seriously defective.

Captive breeding has played a greater or less important part in the conservation of seven species (chinchilla, Asiatic lion, great Indian rhino, European bison, ne-ne, Laysan duck and whooping crane), but only with the chinchilla, European bison and the ne-ne has it progressed to the point where stocks could be returned to the wild, and the chinchilla has been reintroduced not in the Andes but in the high mountains of Soviet Asia.

The control of competing wild species has proved necessary only with the cahow. In no instance has the control of feral domestic animals been necessary.

It is of some interest that the direct intervention of the Survival Service Commission of IUCN has materially affected only two of these mammals, the Javan rhino and Asiatic lion. Governmental bodies have been mainly responsible for the efforts to save most of the rest, notably the United States Bureau of Sport Fisheries and Wildlife for the whooping crane, Laysan duck and California condor. Official bodies in Indonesia, Poland, South Africa, India and Bermuda, have helped with the Javan rhino, European bison, mountain zebra, great Indian rhino, Asiatic lion and cahow. In two instances, the ne-ne and cahow, voluntary bodies or individuals have been largely responsible for the species being saver:.

It must be remembered that this analysis applies only to a rather arbitrary selection of endangered species, which happened to be well known to those conservationists gathered at Lake Success in 1949. The SSC has not in fact played such a small part as this suggests. Its full role in saving endangered species, especially in the past ten years, is the subject of a separate analysis that is now being prepared. 